Article

\title{
Impact of Resources on the Development of Local Entrepreneurship in Industry 4.0
}

\author{
Paweł Kłobukowski * and Jacek Pasieczny *(1)
}

Academic Unit for Entrepreneurship and Management Systems, Academic Subunit for Organizational Innovation and Entrepreneurship, Faculty of Management, University of Warsaw, 02-678 Warszawa, Poland

* Correspondence: pklobukowski@wz.uw.edu.pl (P.K.); jpasieczny@wz.uw.edu.pl (J.P.)

Received: 14 October 2020; Accepted: 29 November 2020; Published: 9 December 2020

\begin{abstract}
The development of Industry 4.0 has a significant impact not only on production processes but also on the functioning and future of regions. It is crucial to understand the phenomena taking place in the social and economic space both from the cognitive and practical point of view. The article is based on research which investigates the prospect of communes in the context of Industry 4.0 development. The aim of the article is to show possible consequences of the development of Industry 4.0 from the local perspective. The basic assumption is a positive impact of entrepreneurship on ensuring sustainable regional development. The model adopted is built on a resource-based view and includes both invariable, external and independent resources such as location, as well as those which are variable in the longer term, such as human and social capital. To verify most of the hypotheses, a linear regression model has been created. The results of the research show that there is a strong correlation between human capital, social capital, proximity of an agglomeration and tourist attractiveness of a region, and regional development operationalised by the number of enterprises. The article presents possible directions of changes in the profiles of local units, as well as the conditions which have to be met in order to enable such a transformation.
\end{abstract}

Keywords: industry 4.0; entrepreneurship; development

\section{Introduction}

The fourth industrial revolution is the result of digitalization of production processes and the growing role of information as well as the application of cyber and physical systems [1]. The term "fourth industrial revolution" came into use in Germany between 2010 and 2011. At that time, a working group Platform Industrie 4.0 was set up, serving as a centre for contacts between the industry, business and science. Hence, Industrie 4.0 has become known as Smart Industry or the Integrated Industry to connect machines and devices, processes and products in intelligent networks [1].

The development of Industry 4.0 raises numerous questions and causes controversy. It has also been the subject of many studies. A considerable number of researchers focus on the technical and business aspects of this phenomenon. The examples of areas studied include tools for quality assurance in the conditions of the technological revolution [2], the impact of the development of Industry 4.0 on specific operational areas [3] or effective business models of enterprises operating in Industry 4.0 [4]. A significant part of the discussion is dedicated to the positive consequences of the development of Industry 4.0 technologies. They are to encourage the development of servicing strategies, design-to-cost approach, supply chain integration, equipment improvement and development of databases as well as the introduction of lean management systems [3]. Moreover, the effects of technological changes will also be visible in the area of costs, in the process of acquiring new skills and making strategic decisions [5] as well as in the financial sector [6]. Other authors indicate improved logistics services, more effective cooperation with partners, better interaction between logistics functions, 
better financial results and competitiveness [7], as well as the ability to increase control and enable real-time performance measurement [8]. Social determinants of the development of Industry 4.0 are also studied. Organisational learning plays an important role in this area. According to Tortorell et al. (2020), companies that promote organisational learning and encourage the sharing of knowledge may reap greater benefits of implemented technologies [9]. Other researchers emphasise the inevitable impact of technological development and artificial intelligence on human resource management [10]. The importance of technological development for solving social problems of developing countries is also analysed [11]. Van Rensburg et al. (2019) argue, that specifically in developing countries, the benefit from technology innovation can significantly impact on socio-economic issues like unemployment and skills development. Technological development is identified as a crucial driver for new growth and a means to develop and outperform foreign competitors [11].

The consequences of technological development are important from the point of view of sustainable development. Although researchers are not unanimous, the majority of them indicate a positive correlation between Industry 4.0 and sustainability. While studying a manufacturing plant that was introducing the "smart factory" technology, Zhang et al. (2019) noticed a lower consumption of raw materials, which allowed the company to reduce the impact on climate by $39 \%$ [12]. Similar conclusions were reached by Varela et al. (2019), who studied the impact of Lean Manufacturing and Industry 4.0 on the three pillars of sustainability: economic, environmental and social. According to those authors, while Lean Manufacturing shows no correlation with any of the three pillars, Industry 4.0 strongly correlates with all of them [13]. Nevertheless, Bonilla et al. (2018) claim that the impact of processes that make up Industry 4.0 on sustainability and the environment is still unknown [14]. Other studies however show an inverse relationship that, e.g., environmental and social opportunities are driving factors for the implementation of Industry 4.0 solutions. [15]. There are also attempts to analyse corporate social responsibility and Industry 4.0 in relation to the young generation. Their aim is to create a sustainable framework of human resource management [16].

Some authors focus on the threats associated with the development of Industry 4.0. Adamik and Nowicki identify as many as 31 key paradoxes and pathologies of building a competitive advantage based on co-creation of companies operating in the age of Industry 4.0. [17]. The problems identified may concern the assurance of the reliability of robot systems and proper human-robot interaction [18] and the organisational resistance of employees and middle management to the implementation of solutions 4.0, caused by the transformation of the management structure [8]. Some authors claim that the development of Industry 4.0 will result in investments being made in Europe again as higher efficiency and productivity levels encourage companies to invest capital in their place of origin [19]. Studies conducted by those authors show a positive correlation between the adoption of technology 4.0 and backshoring propensity. These results are partly confirmed by J. Stentoft and C. Rajkumar (2019), who claim that companies that have relocated their activities back to their headquarters consider the impact of Industry 4.0 to be positive. On the other hand, companies that have not relocated their activities at all perceive this impact negatively [20]. Barbieri et al. argue that the expectations of the most developed countries towards backshoring in terms of job creation in their territory may turn out to be exaggerated due to the fact that companies will decide to relocate only selected product lines [21]. However, assuming that the declarations of some enterprises will translate into practice, it will be a threat to the regions that have played host to investments so far. Other studies indicate the importance of a well-balanced concept of the development of information technology because countries that do not have it are characterised by chaotic development and failure to achieve the objectives pursued [22]. The consequences of the development of Industry 4.0 for the labour market are also unclear [23], although there are undoubtedly concerns related to job losses resulting from technological changes [24].

A relatively small number of studies relate to regional and local consequences of this technological revolution. However, few of them relate to such issues indirectly. For instance, M. Pini (2019) studied the relationship between the tendency to make innovations in the context of the development of 
Industry 4.0 and the hiring of professional managers in family businesses in different parts of Italy. The results show that in more developed regions, external management has a direct influence on the tendency to make innovations, whereas in less developed areas, additional investments in R\&D are still needed [25]. Weng et al. (2019) have analysed the importance of Cultural Heritage Tourism in terms of sustainable development [26]. The impact of Industry 4.0 on the development of tourism has also been studied by Malihah et al. (2018), who have come to the conclusion that the technological revolution requires appropriate skills, including communication, critical thinking and technological skills [27]. The regional aspect has also been noticed by Hedvicakova and Kral (2018), who studied the impact of automation related to Industry 4.0 on unemployment and came to the conclusion that it was very diverse on a regional scale [28]. Other authors also point out to the necessity of proper identification of future educational needs and the possibility of increasing unemployment [29]. Meanwhile, the changes that take place may contribute to a rapid transformation of the economic and social space. This has already been noticed by some regions, which decided to create a development-friendly ecosystem 4.0 [30]. Industry 4.0 places new demands on the number and qualifications of employees in relation to the existing manufacturing models. Manufacturing processes will require fewer employees and the qualifications required of them will be different from the previous ones. At the same time, the demand for workforce in other sectors and, perhaps, in emerging manufacturing industries will increase. All this poses a serious challenge for both entrepreneurs and company managers as well as for territorial unit managers. There are indications that, as a result of such changes, a lot of regions will be forced to look for new development paths and new sources of competitive advantages. Therefore, it becomes important to look for such profiles of territorial units (regions, municipalities, cities) that will enable their development and meet the needs of inhabitants.

The aim of the article is to show possible consequences of the development of Industry 4.0 from the local perspective. The article presents possible directions of changes in the profiles of local units and conditions that have to be met to enable such a transformation. The subject of the study was entrepreneurship measured by the number of companies in single local self-government units in Poland. All 2477 municipalities (basic local self-government units) in Poland were surveyed. The practical aim of the study is to improve the knowledge of the resources that cause an increase in the number of companies over the years. It will help to adapt programmes stimulating entrepreneurship to local realities and present solutions that may become an inspiration to regional authorities in the scope of opportunities and threats generated by the development of Industry 4.0.

This study makes the following contribution to the literature. Firstly, the analysis conducted focuses on the spatial consequences of the development of Industry 4.0. So far, they have not been the main subject of research; in this context, local aspects have only been of secondary nature and accompanied other issues.

Secondly, the research model created is based on a resource-based view. Resources are identified by many authors as a key to the successful implementation of Industry 4.0 technology. This applies to both tangible and intangible resources. The model adopted includes both invariable, external and independent resources (e.g., location), and, in the long term, variables (human and social capital). The model built on resources provides a basis for assessing the prospects of the development of territorial units from the point of view of sustainable development. Thirdly, the analysis of the sustainable development of territorial units in the context of the development of entrepreneurship on their territory, which is operationalised by the number of companies, gives the opportunity to compare a lot of very different entities in many respects.

\section{Materials and Methods}

\subsection{Regional Development and Its Operationalisation}

Regional development is associated by many authors with the development and location of enterprises [31-33]. The local dimension of business development is identified with an increase in 
welfare and living standards, and at the same time, it seems to be a mobile factor that is susceptible to stimulation. Capello and Nijkamp (2009) define this term and the methods in which it is measured in the following way: "Regional development is about the geography of welfare and its evolution. It has played a central role in such disciplines as economic geography, regional economics, regional science, and economic growth theory. The concept is not static in nature, but refers to complex space-time dynamics of regions (or an interdependent group of regions). Changing regional welfare positions are often hard to measure and in practice, we often use Gross Domestic Product (GDP) per capita (or its growth) as a statistical approximation. Sometimes alternative or complementary measures are also used, such as per-capita consumption, poverty rates, unemployment rates, labour force participation rates, or access to public services" [34]. In papers on political economics, one can find the view that regional development should refer to countries, not regions (and focus on global factors and state policy). In this respect, a very high priority is given to global corporations, often based in agglomerations, and capital at the expense of SMEs. Such an approach to regional development theory may lead to the omission of factors stimulating entrepreneurship in underdeveloped regions that need a different path of development. On the other hand, ignoring the regional development in economic analyses makes it difficult to understand the development of large metropolises. An extreme example of this process is the formation of hyperagglomerations, which may have a completely different business cycle than the rest of the country [35]. At the same time, such analyses of political economics ignore the cultural and historical factors that distinguish a region from a country, which is particularly important in countries with wide internal diversity. The current itself aims to combine the macro- and micro-economic perspective by mainstreaming the regional perspective into the discussion about economy.

The operationalisation of the regional development using the number of enterprises may be important in the context of large-scale backshoring. The same authors associate the phenomenon of backshoring with development of Industry $4.0[19,20,36]$. Backshoring poses a considerable threat to those regions that in recent years have been the destination of relocation. Such phenomena occurring on a mass scale may lead to higher unemployment. Fear of losing job stability due to technological changes is often indicated by employees [24]. Backshoring, by definition, applies to those companies that have already relocated their activities, usually bigger, more flexible companies that have more capital and bigger intellectual resources. Regions affected by backshoring will be able to maintain their economic well-being if there are other deeply rooted businesses that pay taxes and employ inhabitants. Therefore, the key issue is to identify those resources that will contribute to the creation and functioning of enterprises in a specific region. In this context, the adoption of the resource-based view as a theoretical basis for research is a consequence of the outlined research problem. This approach is presented, among others, by Hindle (2010, p. 606), which refers to the metaphor of garden [37]. An entrepreneur, like a gardener, is not able to control all the variables around $\mathrm{him} / \mathrm{her}$. When we grow plants, the effects of our work also depend on the weather, temperature, wind or rainfall. Additionally, whether a company will be successful also depends on macroeconomic factors. According to Hindle, the main problem preventing the provision of external aid to local communities (and not only) is a poor diagnosis of the context and a lack of targeted measures, which results from the lack of an analytical framework e.g., for determining the impact of the local community on the entrepreneurial process. According to him, it creates a huge research gap. Entrepreneurship is affected by three types of resources: human, physical and institutional [37]. These three elements become the basis for describing the relationship between the local context and the entrepreneurial process. Other studies on the economic profiles of regions have focused on resources such as: specific (rare) natural resources, historical factors, social capital, leadership and management, regulations and external actions [38]. Referring to the concept of the regional entrepreneurial process, Tamásy (2006) presents the development of entrepreneurship in selected German regions [39]. Based on the data from the "Regional Entrepreneurship Monitor" and the "New Firm Survey", the author points out that the three main groups of explanatory variables in the entrepreneurship surveys refer to the establishment 
of new companies, the entrepreneur and external factors, such as geography or the industrial nature of the environment.

\subsection{Hypotheses}

This study analysed the resources that affect the process of increasing the number of companies operating in municipalities- the basic and smallest territorial division units in Poland. The main variable explained is the number of enterprises entered in the database of the National Official Register of Business Entities per 10,000 inhabitants. The register is the only available source of such data in Poland. One of its main flaws is the fact that it does not provide the number of active companies. However, the fact that companies are not deregistered concerns the whole country, so it will still be possible to compare the number of businesses at the level of municipalities, even if it will be slightly overstated. The most important explanatory variables include human capital, social capital, presence in the voivodship agglomeration and tourism. The research method used to verify the research hypotheses is linear regression. The following hypotheses were made:

The first hypothesis assumes that human capital (operationalised by the percentage of individuals with higher education) is positively correlated with the number of inhabitants per 10,000 inhabitants. This is affected by the fact that university graduates have a high human capital [40]. The thesis that human capital, understood primarily as formal education, is an important factor determining the creation and development of new enterprises is present in the literature on the development of entrepreneurship. In the condition of the development of Industry 4.0, human capital and education play a key role [41]. It is assumed that people with higher education will be more likely to set up their own businesses than those that are less educated. They will do so effectively, and their business activities will bring measurable benefits [42-44]. Education gives individuals the knowledge necessary to see the opportunity to start a business in the world around them [44,45]. Furthermore, it is argued that education provides individuals with the cognitive skills necessary to facilitate the acquisition of new knowledge and adaptation to new situations. It is also believed that education increases the productivity of individuals and enhances their management skills, which in turn increases the chances of starting their own businesses [41]. There is a positive relationship between human capital and innovation [46], which drives development of Industry 4.0 [47]. However, the arguments in favour of the opposite thesis indicate that higher education often goes hand in hand with jobs involving higher salaries, which discourages people from starting their own businesses [45]. The study conducted by Kim, Aldrich and Keister (2006) shows that out of the three forms of capital, i.e., financial, cultural and human capital, human capital is the only factor strongly affecting the chances to start business successfully [42]. Higher education and management experience give people establishing their own companies a significant competitive advantage over other individuals. The fact that human capital is considered to be one of the main factors determining the economic development of countries, regions, and lower-level local self-governments is extremely important from the point of view of the study conducted [48]. A pioneering study in this respect was carried out by Mankiw et al. (1992); it indicated a strong macro-level relationship between the Gross Domestic Product per capita of individual countries and the percentage of people with higher education. In this paper, the human capital of individual municipalities is measured as the percentage of individuals with higher education, living in a given municipality [48].

The second hypothesis assumes correlations between the number of enterprises per 10,000 residents and social capital, and that this resource will have a positive estimator statistically significant in the model. To properly understand entrepreneurship, one has to take social conditions of this phenomenon into account [49]. Despite the fact that they are increasingly perceived by researchers and theorists as important and that they more and more often become the subject of empirical research, there is no coherent theory that would organise the research work conducted in this area [49]. The use of the concept of social capital for research on entrepreneurship is hindered by the theoretical confusion around the very concept of social capital. There is no one universal way to understand this concept. 
According to Robert Putnam (1993), social capital is understood as trust, standards and social networks (i.e., interconnections between individuals) that make it easier for social groups to take coordinated actions and achieve their goals [50]. However, according to Pierre Bourdieu (1986), social capital is the sum of the actual and potential resources embedded within, available through, and derived from social networks by individuals [51]. Both these ways of understanding social capital are used interchangeably in research on the development of entrepreneurship [49,52], which, on the one hand, allows for a better exploration of the impact of social capital on the creation and development of enterprises, but, on the other hand, makes it difficult to reach a conceptual agreement. The fact that in the research practice, social capital is identified with one of its components, i.e., trust, is an additional difficulty [52]. Trust can be understood as the perceived probability that others will act in the expected manner [53]. The problem of associating social capital with trust concerns both the theoretical level-when trust is treated as a concept equivalent to social capital—and the empirical level—when social capital is operationalised through trust. The operationalisation of social capital through trust probably results from two facts: firstly, from the difficulty in measuring social capital, understood as a set of resources contained embedded in social networks, and secondly, from the key role that trust plays in the creation of social capital as defined by Putnam and Bourdieu [49,52]. From the point of view of research on entrepreneurship, the identification or operationalisation of social capital through trust is a favourable circumstance. If social capital is considered to be a factor contributing to the development of entrepreneurship, it is very likely that the causal mechanism underpinning such a relationship is in fact trust. Research conducted in the automotive industry shows that low social capital: lack of mutual trust between entrepreneurs, and sometimes even mutual hostility, unwillingness to cooperate, lack of courage in undertaking risky investments are perceived by managers as a main barriers of the development of industry 4.0. [53]. However, the Industry 4.0 involves both human and artificial participants and imposes human-human, artifact-artifact, and human-artifact relationships in the system. This requires comparable interpretation and representation of trust in several areas [54].

Adopting the definition of social capital given by Putnam with the corresponding institutional and generalised trust makes it possible to use data at both the individual and the aggregate level. Empirical analyses carried out in this paper concern the development of entrepreneurship in Polish municipalities. The data that can be used to measure social capital at the aggregate level refer to the number of associations operating in a given municipality per 10,000 inhabitants (a similar way to operationalise social capital was chosen by Putnam himself). The data come from the local data bank from 2018. It is worth emphasising that such data measure not so much the resources held by individuals, i.e., the form of social capital affecting the creation of new enterprises and being particularly important in case of the institutional weakness of the state, as the "quality" of the social context as a factor conditioning the development of enterprises in case of stable state institutions.

The third hypothesis assumes a positive correlation between the number of enterprises per 10,000 inhabitants and the location of municipalities that is attractive to tourists (especially municipalities located by the sea or in the mountains) and that the resource will have a positive estimator statistically significant in the model. Tourist attractiveness is strongly connected with the brand of a given region, with how tourists (customers) perceive and position towns [55]. The brand of the municipality can be understood as "a favourable perception of a given municipality by certain recipients as compared to others" [56]. One of the areas of activity of this concept is therefore tourism, where local leaders become active players. Resources, especially natural resources, play a key role and become the reason for the success of tourism. They are largely endogenous. Nowadays, city tourism, which is characterised by much less seasonality, is becoming more and more visible. Using the terminology of the management sciences, it can be said that the image of a given place as well as social and demographic trends are increasingly important. This results in cities attracting customers through attractions not related to nature, such as Las Vegas, which gathers gambling enthusiasts, or Czech, Polish, Hungarian and Latvian city centres, which become, for example, popular places for stag or hen parties. This trend increases the management of customer acquisition by adapting the space to the expectations of the 
demand side. In the new tourist paradigm [57], the key features motivating the customer include education, excitement, and entertainment increasingly often. Tourism has been quick to jump onto the emerging Industry 4.0 trend, embracing increased technological development within its own framework of Tourism 4.0 [58]. Tourism 4.0 may be referred to as a new tourism value eco-system built upon a highly technology-based service production paradigm and supported by the common principles of Industry 4.0, namely interoperability, virtualization, decentralization, real-time data gathering and analysis capability, service orientation, and modularity [59]. Tourists become more educated and open to travel; companies and associations play an increasingly important role in ensuring the development of tourism, whereas the Internet becomes the dominant form of promotion and customer acquisition. In the study, it was decided to operationalise the variable "tourist attractiveness" as the number of searches for the municipality name in Google per capita per month. The data on searches were transcribed from the keyword panel. Then, they were divided by the number of inhabitants (data from the local data bank). In case the municipality name derived from another language, which resulted in an increased number of searches from abroad, the option "data from Poland only" was activated. If the municipality name was identical to another word (e.g., Hanna, Ropa, Złota) and this word appeared first in Google, the query was changed to "Municipality X (where x means the municipality name)". Several corrections have been made to individual cases (as in the case of Barlinek municipality, where searches for a company with the same name were subtracted). In total, about 138 changes were made to the searches. An additional difficulty was importing data from the keyword panel. This could not be done through a script and therefore the number of searches had to be copied by the authors.

The fourth hypothesis assumes a positive correlation between the presence of the municipality in the agglomeration and the number of enterprises per 10,000 inhabitants. The relations between the region and the city have become a very early and important subject of analyses of regional development, starting with Christlaller, Perroux or Krugman [60-62]. In recent period, a clear metropolisation of development, i.e., concentration of the most modern sectors in the largest cities, whose quality features allow them to occupy an important place in the global metropolitan network [63-65]. This is also one of the consequences of development of Industry 4.0. The research carried out shows that new companies are located in regions where investments were already present $[66,67]$. This can be explained at the microlevel by the success of spin-offs or diversifying firms, that can leverage their preentry experience in related industries, compared to entrepreneurs and firms with little or no experience, and at the mesolevel by the externalities from the local presence of related industries [68]. In the further part of the analysis, the main category will be agglomeration, which is the last phase of urbanisation consisting in the transformation of urban spaces and change of the relationship between the central city and its direct background and discontinuous use of urbanised spaces. It manifests itself as a weakening or severing of the city's economic links with its regional background and replacing them with contacts with other metropolises on a continental or global scale. Thus, this approach is consistent with the one presented by Friedman [63], pointing to the emergence of global cities that will be economically more connected with the global economy than with the national economy. The metropolis is starting to compete with other cities for human capital or resources valuable for international corporations. Some of the infrastructure causing social reluctance is moved outside the cities (such as landfills or waste-sorting plants), which indicates the negative aspects of the metropolisation process for the region. In this study, a dummy variable was used to indicate membership in a voivodship agglomeration. In each voivodship, the municipalities directly adjacent to the capital city of the voivodship were treated as part of the agglomeration. Metropolis and agglomeration, due to the type of data at the quantitative level, are considered to be identical.

The fifth hypothesis assumes that entrepreneurship management in a municipality is a trace phenomenon and the development of entrepreneurship is determined mainly by the resources of a given local self-government. Therefore, the linear regression model will have a highly explanatory value. It is i.a. the result of the analysis of the legal status within which the Polish regions operate. Polish local self-governments at all levels have very limited possibilities of participating in and 
undertaking economic activities, the sources of income of local self-governments are limited and very well defined. The possibilities of providing financial incentives to investors are also highly limited. This concerns both exo- and endogenous entrepreneurship. At the same time, the statistics show very large differences in the economic condition and development level of municipalities.

A summary of the operationalisation is shown in the Figure 1 below:

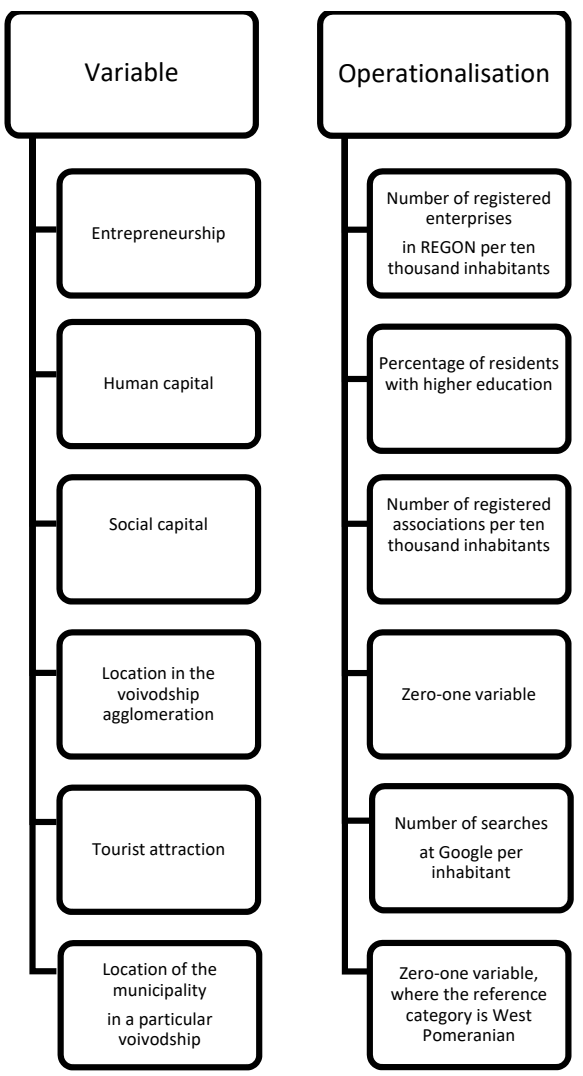

Figure 1. A summary of operationalization of variables (human capital. Social capital, etc.).

\subsection{Methodology}

\subsubsection{Data Sources}

To verify most of the hypotheses, a linear regression model was created using the least squares method. It gives unloaded and effective estimators provided that the assumptions of the Classic Linear Regression Model are met. All municipalities in the country were analysed. The analysis was based mainly on data from the Local Data Bank, as well as on those obtained from Google, while some of the dummy variables were created based on the selected criteria. The analysis of tourist municipalities proved to be a great difficulty. In order to create an explanatory variable, it turned out to be necessary to copy the results from the Google database manually for all observations, as all attempts to acquire the data mechanically were blocked by the application. At the same time, during the copying of the results, the manner of data presentation has changed from the accurate data to ranges "from-to". The change was made when the results for the main atypical observations had already been copied to the database. However, it is not possible to create a similar database with the current way of data presentation. The data analysis showed that ten out of twenty observations with the highest score in terms of the number of companies per ten thousand inhabitants in the country are tourist municipalities. They took extremely high values for the explanatory variable. Therefore, in order to maintain methodological correctness, it was decided to introduce logarithmic variables into the regression model, which had a positive impact on the quality of the fitting. Tests of correct model specification (RESET test) and 
Breusch-Pagan test for homoscedasticity of variance of random error were carried out. There is also an interaction between the tourism variable and human capital.

\subsubsection{Regression}

The estimated model can be recorded for the $i$-th observation unit (municipality) as follows: Enterprises $_{i}=\beta_{1}+\beta_{2} \times$ Human capital $_{i}+\beta_{3} \times$ Social capital $_{i}+\beta_{4} \times$ Tourism $_{i}+\beta_{5} \times$ Agglomeration $_{i}$ $+\beta \times$ Voivodship $_{\mathrm{i}}+\varepsilon_{\mathrm{i}}$.

The dependent variable, defined as "enterprises", is the number of enterprises registered in the municipality in the REGON database per ten thousand inhabitants. The predictors used for estimating the value of the dependent variable include: human capital operated as a percentage of persons with higher education in a municipality; social capital, defined as the number of associations registered in the municipality per ten thousand inhabitants; tourist brand of the municipality (hereinafter referred to as "tourism"), measured through the number of searches for the name of the municipality in the Google browser per one inhabitant of the municipality, and its presence or lack of presence within the voivodship agglomeration (surrounding the capital of the voivodship).

The other elements of the model presented are interpreted as follows:

- $\quad \beta_{1}$-is an incerpt parameter of the model. This parameter is equal to the value of the predicted dependent variable when all independent variables equal zero;

- $\beta_{2}, \beta_{3}, \beta_{4}, \beta_{5}$-are parameters of the corresponding variables (human capital, social capital, tourism and agglomeration, respectively) which measure the impact of these variables on the dependent variable;

- $\quad \beta \times$ Voivodeship—is a vector of parameters estimated for the vector of dummy variables identifying the voivodeship to which the municipality belongs;

- $\quad \varepsilon$-is a random error;

- $\quad \mathrm{i}$-is an index of the observation unit (municipality).

\section{Results}

\section{Study Results}

The distribution of the dependent variable is shown in Figure 2 below, and Table 1 shows its parameters.

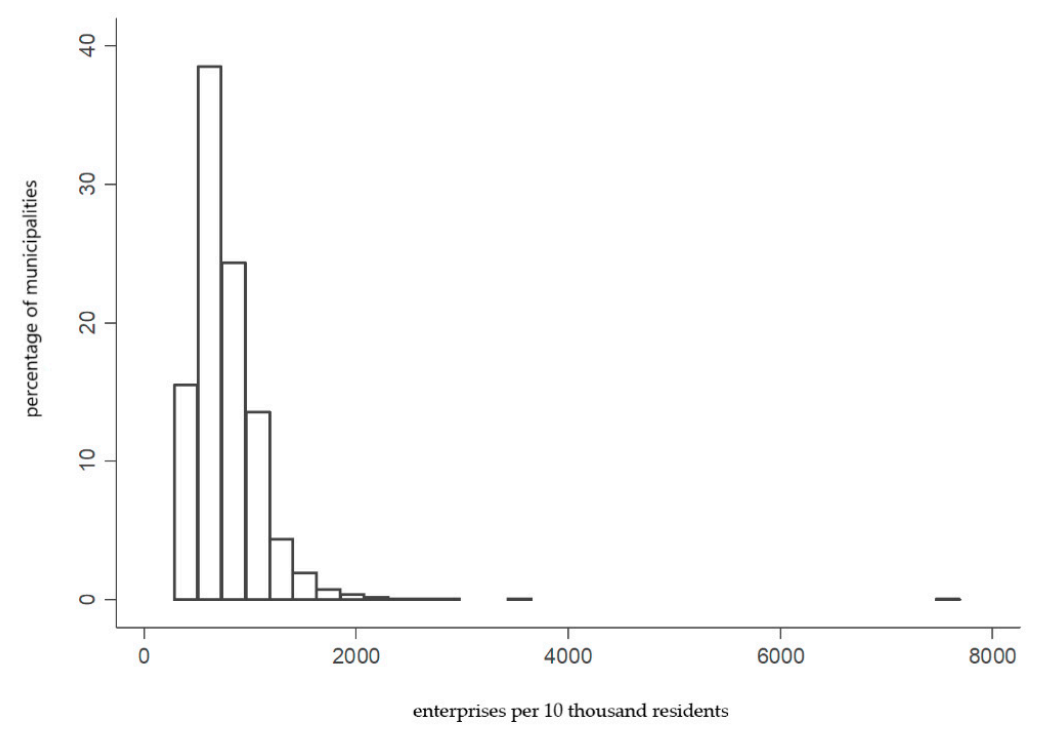

Figure 2. Number of enterprises in the municipality-variable distribution. Source: own elaboration. 
Table 1. Number of enterprises in the municipality-parameters of variable distribution.

\begin{tabular}{lccccccc}
\hline Variable & Mean & sd & Skewness & p50 & Min & Max & N \\
\hline Enterprises & 778.27 & 343.66 & 5.089 & 708.48 & 283.15 & 7691.5 & 2478 \\
\hline
\end{tabular}

Table 1 shows that the average number of enterprises (per ten thousand inhabitants) in Polish municipalities is 778. The Figure shows that the distribution of the dependent variable is strongly rightward: most of the observations (municipalities) are in the initial part of the distribution. For 2458 municipalities, i.e., $99 \%$ of the observations, the number of registered enterprises does not exceed 2 thousand per ten thousand inhabitants. At the same time, a small number of observations is far from the central value of the distribution. Extreme values in this range can be observed for the following municipalities (Table 2 below):

Table 2. Number of enterprises in the municipality-atypical observations.

\begin{tabular}{ccc}
\hline Municipality & Number of Companies per 10,000 Inhabitants & Type of Municipality \\
\hline Karpacz & 7691.53 & Tourist municipality (mountains) \\
Krynica Morska & 3588.01 & Tourist municipality (sea) \\
Rewal & 3525.74 & Tourist municipality (sea) \\
Łeba & 3480.19 & Tourist municipality (sea) \\
Jastarnia & 2956.54 & Tourist municipality (sea) \\
Mielno & 2855.18 & Tourist municipality (sea) \\
Ustronie Morskie & 2718.42 & Tourist municipality (sea) \\
Lesznowola & 2703.45 & Agglomeration municipality \\
(near Warsaw) \\
Międzyzdroje & 2699.38 & Tourist municipality (sea) \\
Władysławowo & 2406.19 & Tourist municipality (sea) \\
Dziwnów & 2318.05 & Tourist municipality (sea) \\
Sopot & 2305.47 & Tourist municipality (sea) \\
Podkowa Leśna & 2252.28 & Agglomeration municipality \\
(near Warsaw) \\
Capital City of Warsaw & 2210.49 & Agglomeration \\
Łomianki & 2165.87 & Agglomeration municipality \\
(near Warsaw)
\end{tabular}

The main atypical observations constitute the municipalities which are a strong brand as centres of mountain tourism (Karpacz, Zakopane) and coastal tourism (Mielno, Krynica Morska, Rewal, Łeba, Jastarnia, Międzyzdroje, Władysławowo). Another group is the municipalities which are part of an agglomeration-especially Warsaw and Poznań. Sopot and Podkowa Leśna are the municipalities which are both part of an agglomeration and have the highest percentage of people with higher education in Poland. The high score of Podkowa Leśna constitutes an interesting case. The town is distinguished by a very high level of entrepreneurship despite the lack of investment plots. Interviews conducted in Podkowa Leśna showed that the key skill of this municipality is attracting "valuable" residents. Many presidents of companies, actors and artists who identify themselves with this town live there and therefore pay taxes there. The example of Podkowa Leśna indicates that an important aspect of the analysis is the answer to the question: what determines the choice of the municipality to be inhabited by the most valuable settlers in terms of paying taxes? 
Below, Figures 3-5 present distribution of three independent variables, i.e., human capital, social capital and tourism. In turn, Table 3 shows the distribution parameters of the above variables.

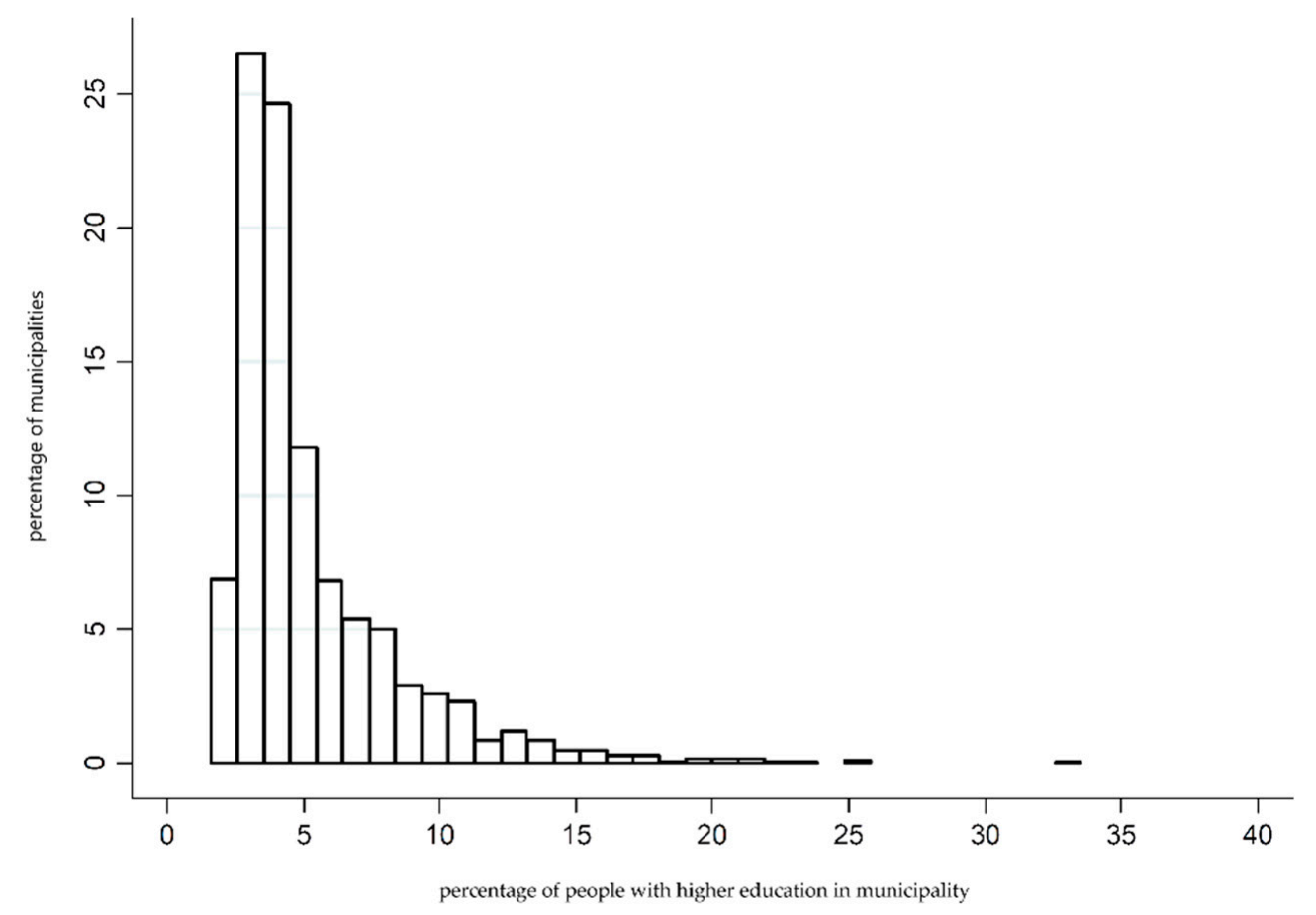

Figure 3. Human capital-variable distribution. Source: own elaboration.

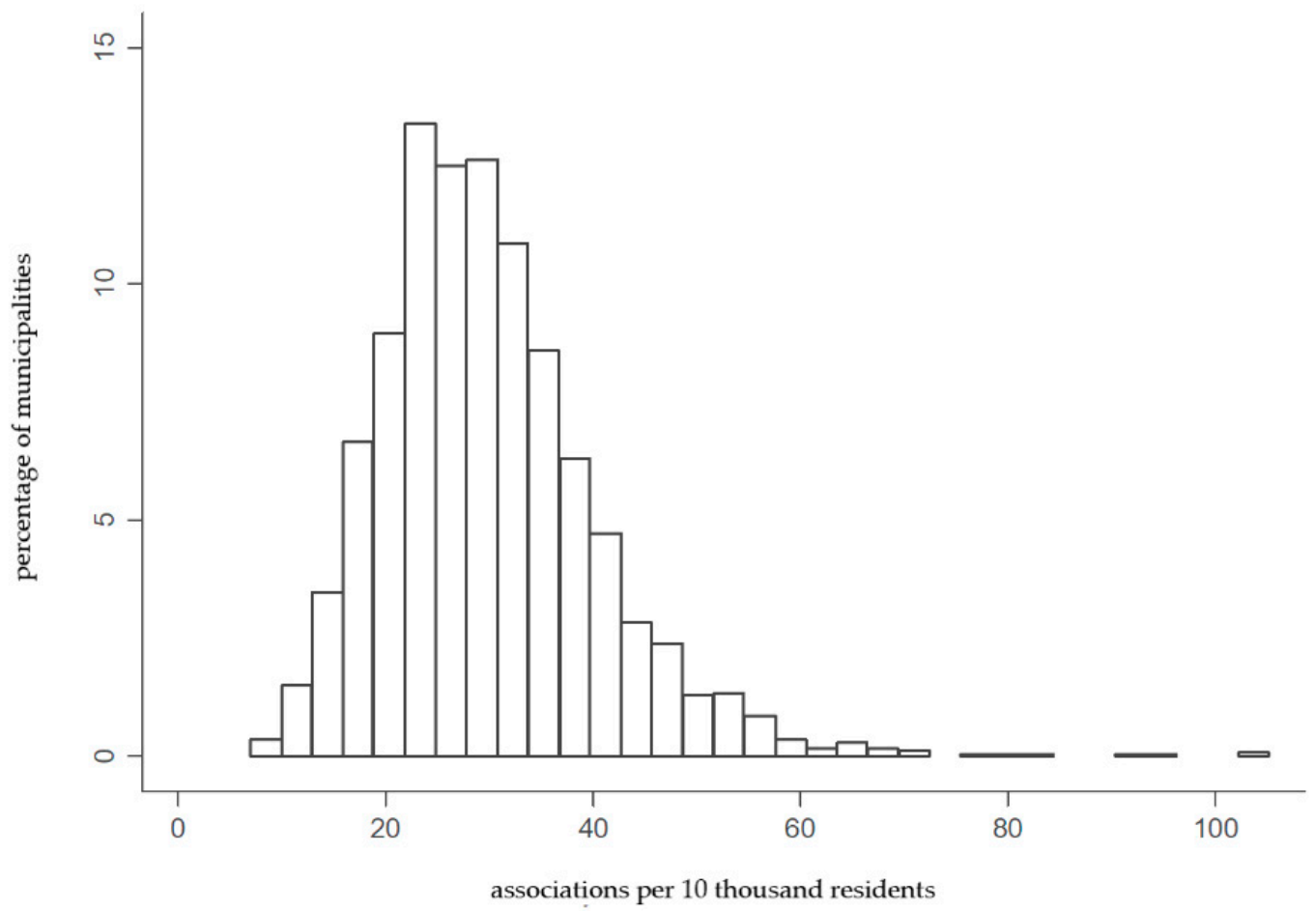

Figure 4. Social capital—variable distribution. Source: own elaboration. 


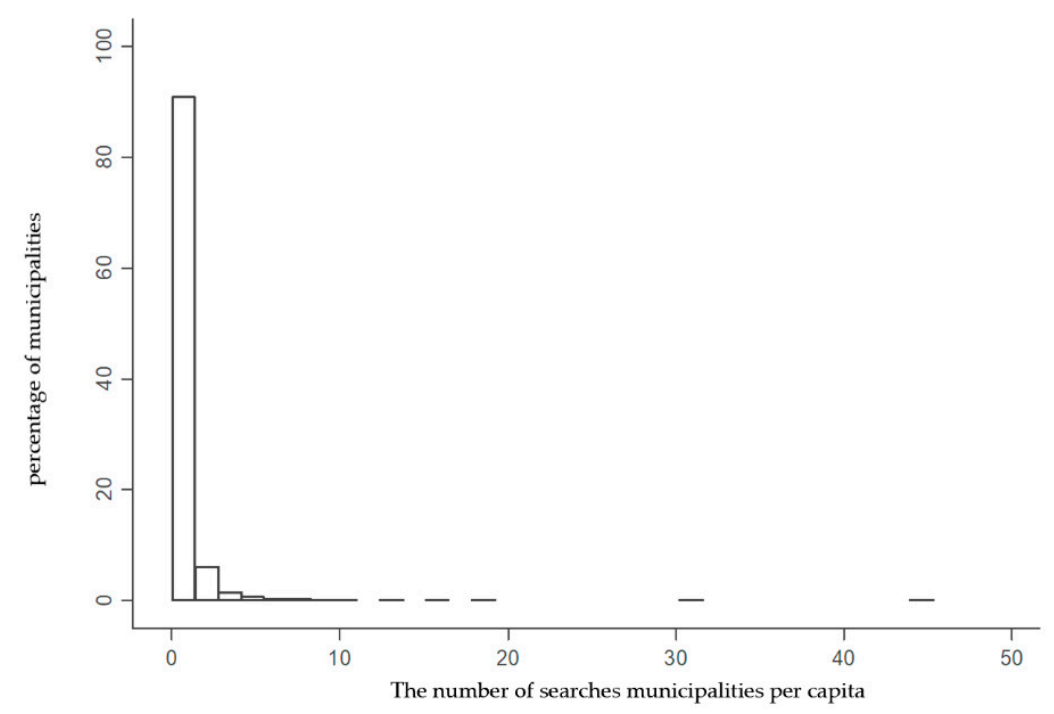

Figure 5. Tourism—variable distribution. Source: own elaboration.

Table 3. Human capital, social capital, tourism—distribution parameters.

\begin{tabular}{|c|c|c|c|c|c|c|c|}
\hline Variable & Average & Deviation Standard & Skewness & Median & Min & Max & $\mathbf{N}$ \\
\hline $\begin{array}{l}\text { Human } \\
\text { capital }\end{array}$ & 5.244 & 3.145 & 2.3643 & 4.106 & 1.613 & 33.531 & 2478 \\
\hline social capital & 29.856 & 10.398 & 1.2565 & 28.525 & 6.995 & 105.22 & 2478 \\
\hline Tourism & 0.71549 & 1.5549 & 14.885 & 0.40327 & 0.00744 & 45.318 & 2478 \\
\hline
\end{tabular}

As can be seen in the presented Figures (Figures 3-5), human capital, social capital and tourism have rightward skewed distributions-with an elongated right arm and most of the observations located near the minimum (and central) value of the distribution. This is also evidenced by the positive values of the skewness coefficient shown in Table 3. The distribution of the tourism variable is characterised by the largest skewness, it is strongly rightward skewed-the skewness coefficient is 14.9 and the standard deviation exceeds the expected distribution value more than twice. The Figure of this variable shows many single observations, for which the values of this variable differ significantly from the mean value and the distribution median. Table 4 presented below presents the 20 most atypical municipalities in terms of search frequency.

Table 4. Number of municipality searches per 1 inhabitant per month-atypical observations.

\begin{tabular}{ccc}
\hline Municipality & Number of Searches per 1 Inhabitant & Type of Municipality \\
\hline Krynica Morska & 45.32 & Sea \\
Hel & 30.61 & Sea \\
Karpacz & 18.39 & Mountains \\
Łeba & 15.77 & Sea \\
Ustronie Morskie & 13.39 & Sea \\
Rewal & 13.00 & Sea \\
Solec Zdrój & 9.84 & Łagów \\
Health Resort & 9.84 & Landscape park-lakes \\
Mielno & 9.74 & Sea \\
Białowieża & 9.73 & National Park-forest \\
Solina & 9.39 & Mountains \\
Szklarska Poreba & 8.86 & Mountains \\
Kazimierz Dolny & 8.77 & Architectural complex \\
Jastarnia & 8.56 & Sea \\
Świeradów Zdrój & 7.68 & Bałtów \\
\hline
\end{tabular}


Table 4. Cont.

\begin{tabular}{ccc}
\hline Municipality & Number of Searches per 1 Inhabitant & Type of Municipality \\
\hline Health Resort & 7.59 & Jurassic park, ski station \\
Międzyzdroje & 7.52 & Sea \\
Zakopane & 7.29 & Mountains \\
Pabianice & 7.27 & $\begin{array}{c}\text { Park, monuments, proximity } \\
\text { of the agglomeration (Eódź) } \\
\text { National Park-forest, } \\
\text { monuments }\end{array}$ \\
\hline
\end{tabular}

The number of queries in the Google browser per person represents the image of the municipality as a tourist destination. For businesspeople who rent rooms to tourists, the main source of customers are portals such as Booking.com, nocowanie.pl, etc. The highest score in terms of the number of searches in the Google browser per person has Krynica Morska, which is very much influenced by the relatively small number of inhabitants of this municipality. Karpacz is the only non-coastal municipality with more than 10 searches per inhabitant. At the same time, it is a less monthly differentiated search with much lower maximum values. While in coastal municipalities, the seasonality of Google queries is becoming apparent. Out of 20 observations with the highest number of queries per one inhabitant in Google, 8 are coastal municipalities, 5 municipalities are related to mountain tourism and the rest to specific local values or attractions (including health resorts). Municipalities on this list have very high values of entrepreneurship density. Two representatives of eastern Poland stand out with much lower results in comparison with the remaining eighteen: Solec-Zdrój has 579 enterprises per 10,000 inhabitants and Bałtów 580. Therefore, we can advance a thesis that, despite considerable recognition and numerous queries in Google, municipalities from the east of the country derive much lower benefits from their brand than others (especially those from Lower Silesia). The reasons for such results can be found in the generally lower affluence of this part of Poland, as well as in the poorer clearway with large urban centres. The statistical analysis points out, however, to the interaction between human capital and tourism (discussed below). Bałtów and Solec-Zdrój, despite their high recognition, do not show high entrepreneurship density results. Possible, this is caused by the very low percentage of people with higher education in both municipalities, which is only $3.6 \%$. Therefore, a hypothesis can be put forward for further research that entrepreneurship in tourist municipalities can only develop after reaching a certain level of human capital. In order to achieve tourist success, human potential is necessary to see the opportunities and take risks associated with one's own business. A key skill in tourist municipalities becomes managing one's own brand on the Internet (both on the part of the municipality and the entrepreneurs themselves) and attracting customers there. Due to the new way of winning customers, such municipalities need educated people with marketing experience. The task of local self-governments focusing on tourism will thus be to skilfully support the villages in order to attract or retain people with high human capital. It also seems to be crucial from the point of view of the need to adjust the potential of municipalities to the requirements of Industry 4.0, the development of which, as previously indicated, will require the development of human capital.

To sum up, the variable "tourism" has a lot of atypical observations with very high values. In the case of two subsequent independent variables-human and social capital-their distributions can also be considered rightward, however, in this case the number of atypical observations lying at the right extreme of the distribution is much smaller than in the case of the tourism variable. Tables 5 and 6 present the most atypical observations for human capital and social capital variables. 
Table 5. Percentage of people with higher education in the municipality—atypical observations.

\begin{tabular}{ccc}
\hline Municipality & $\begin{array}{c}\text { Percentage of People with } \\
\text { Higher Education }\end{array}$ & Type of Municipality \\
\hline Podkowa Leśna & 33.53 & $\begin{array}{c}\text { Agglomeration municipality (Warsaw) } \\
\text { Tourist municipality (sea), in an } \\
\text { agglomeration (Gdańsk, Gdynia) }\end{array}$ \\
Sopot & 25.40 & Agglomeration \\
Capital city of Warsaw & 25.33 & Agglomeration municipality (Warsaw) \\
Michałowice & 25.18 & Agglomeration municipality (Szczecin) \\
Dobra Szczecińska & 21.95 & Agglomeration municipality (Warsaw) \\
Piaseczno & 21.62 & Agglomeration \\
Rzeszów & 21.56 & Agglomeration \\
Lublin & 21.29 & Agglomeration \\
Kraków & 21.01 & Agglomeration municipality (Poznań) \\
Suchy Las & 20.86 & Agglomeration \\
Opole & 20.79 & Agglomeration \\
Wrocław & 20.28 & Agglomeration \\
Kielce & 20.26 & Agglomeration \\
Puszczykowo & 19.97 & Agglomeration \\
Poznań & 19.93 & Agglomeration municipality (Poznań) \\
Olsztyn & 19.79 & Agglomeration municipality (Warsaw) \\
Łomianki & 19.55 & Agglomeration municipality (Warsaw) \\
Lesznowola & 18.98 & Agglomeration municipality (Warsaw) \\
Józefów & 17.89 & Agglomeration \\
Gdynia & 17.89 & \\
\hline
\end{tabular}

Table 6. Number of associations in the municipality per ten thousand inhabitants-atypical observations.

\begin{tabular}{ccc}
\hline Municipality & $\begin{array}{c}\text { Associations per Ten } \\
\text { Thousand Inhabitants }\end{array}$ & Type of Municipality \\
\hline Białowieża & 105.22 & Tourist municipality-national park-forest \\
Cisna & 104.29 & Tourist municipality-mountains \\
Sopot & 96.14 & Tourist municipality in an agglomeration \\
(Gdańsk, Gdynia) \\
Lutowiska & 90.82 & Tourist municipality-mountains \\
Krynica Morska & 82.40 & Tourist municipality-sea \\
Mielno & 78.71 & Tourist municipality-sea \\
Podkowa Leśna & 78.02 & Agglomeration municipality (Warsaw) \\
Nowe Warpno & 71.94 & Agglomeration municipality (Szczecin) \\
Karpacz & 71.12 & Tourist municipality-mountains \\
Capital City of Warsaw & 71.00 & Agglomeration municipality (Warsaw) \\
Pęcław & 69.11 & Rural municipality near an industrial centre \\
Suraż & 68.86 & Agglomeration municipality (Białystok) \\
Krempna & 67.22 & Rural municipality (mountains) \\
Sosnówka & 67.14 & Rural municipality \\
Czarna & 66.31 & Rural municipality \\
Szklarska Poreba & 65.90 & Tourist municipality (mountains) \\
Sokolniki & 65.68 & Rural municipality \\
Biały Bór & 65.52 & Rural municipality \\
Płużnica & 65.28 & Rural municipality \\
Uście Gorlickie & 65.15 & \\
& & Rural, tourist municipality (mountains) \\
\hline
\end{tabular}

The municipalities with the highest percentage of people with higher education are cities such as Warsaw, Poznań, Wrocław, Gdynia, Kraków etc. Often these are academic cities and university graduates look for opportunities on the local labour market. A large group consists also of representatives of the Warsaw agglomeration (Michałowice, Piaseczno or Łomianki), and a smaller group of representatives of Poznań or Szczecin agglomeration (Dobra Szczecińska). In the comparison 
of twenty observations with the highest percentage of people with higher education, there is no municipality that would be located outside the agglomeration of the capital city of the voivodship.

Atypical observations of municipalities with a large number of associations in relation to the number of inhabitants are often tourist municipalities like Białowieża or Mielno. In these towns, the associations, apart from referring to the tradition of the "small homeland", also perform duties commissioned by the municipality, especially the management of tourist traffic. Interestingly, this variable is dominated by municipalities associated with mountain tourism, not coastal tourism. The second visible group constitute municipalities with large human capital, such as Sopot or Warsaw.

Table 7, presented below, shows the conditional parameters of the distributions of the explained variable, depending on whether the municipality belongs to an agglomeration or not.

Table 7. Parameters of conditional distributions of the dependent variable in relation to an agglomeration.

\begin{tabular}{cccccccc}
\hline Variable & Average & Deviation Standard & Skewness & Median & Min & Max & N \\
\hline Agglomeration & 1051.4 & 373.81 & 1.6687 & 979.26 & 428.25 & 3588 & 402 \\
Non-aglomer. & 725.39 & 311.02 & 7.2847 & 672.29 & 283.15 & 7691.5 & 2076 \\
\hline
\end{tabular}

As indicated by the data included in Table 7, municipalities belonging to an agglomeration are characterised by a much higher level of entrepreneurship than municipalities not being part of an agglomeration. In case of the first group of municipalities, the average number of enterprises registered in a municipality is 1051, while for the second group of municipalities, the average is 725 .

The relationship between the continuous independent variables and the dependent variable is illustrated in Figures 6-8 below.

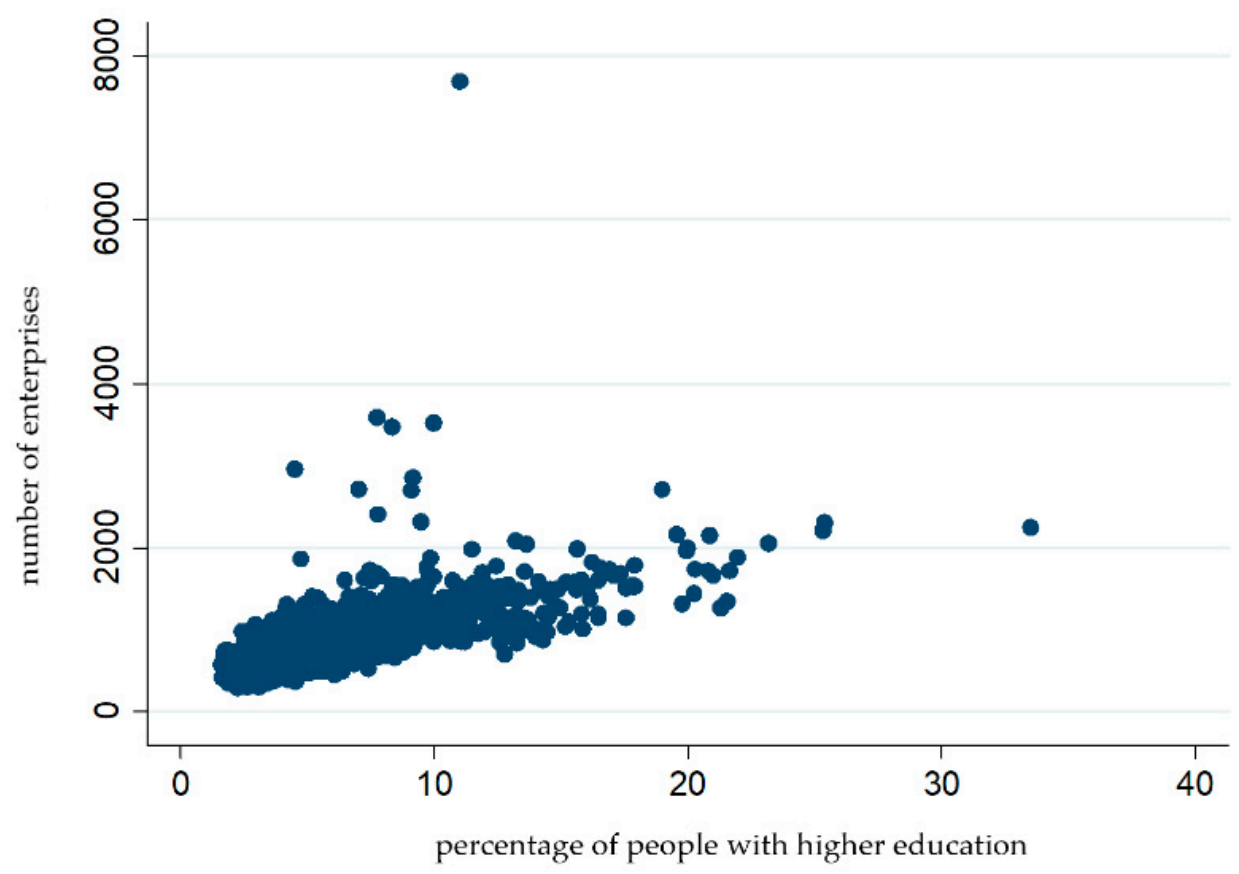

Figure 6. Number of enterprises in a municipality in relation to human capital. 


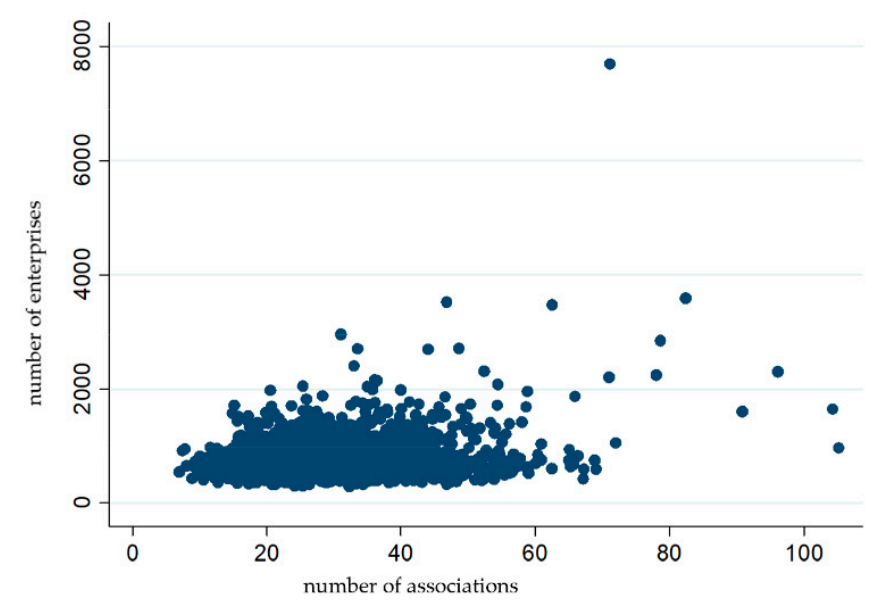

Figure 7. Number of enterprises in a municipality in relation to social capital.

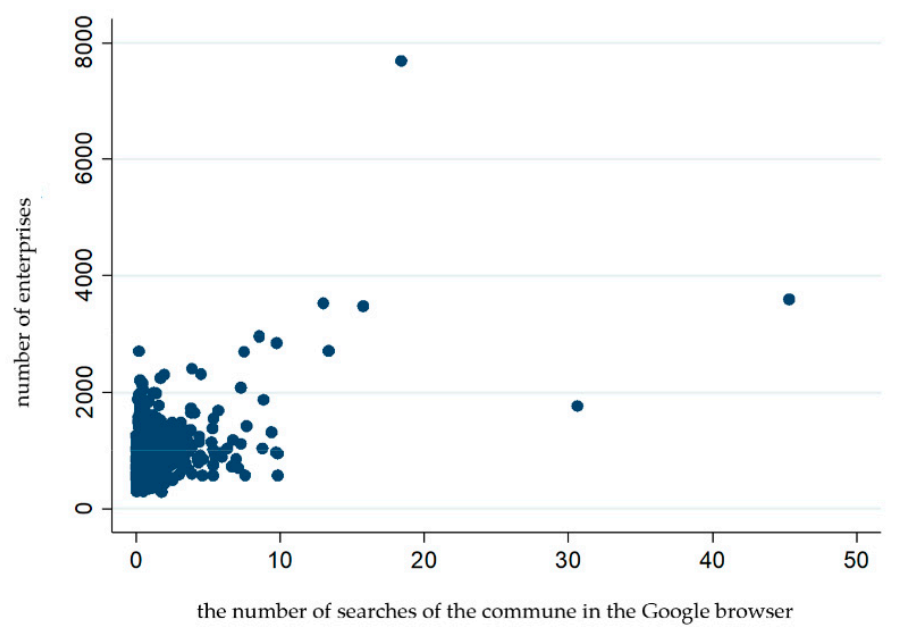

Figure 8. Number of enterprises in a municipality in relation to tourism.

From among the presented two-variable relationships, the linear relationship between human capital and entrepreneurship is clearly visible (Figure 6). The relationships between the other variables-social capital and tourism and entrepreneurship—seem less clear (Figures 7 and 8). In case of all three Figures there are atypical observations—-far from the other observation units.

The transformation of all continuous variables of the model into logarithms has made the dominant majority of relationships between the independent variables of the model and entrepreneurship statistically significant (except for the Hel observation, see Table 8).

Table 8. Model parameter estimates on logarithms—non-standardised coefficients.

\begin{tabular}{|c|c|c|c|c|c|c|}
\hline Source & SS & df & \multicolumn{2}{|c|}{ MS } & \multicolumn{2}{|c|}{ Number of obs $=2478$} \\
\hline Model & 234.493766 & 22 & \multicolumn{2}{|c|}{10.6588075} & \multicolumn{2}{|c|}{$\begin{array}{c}\mathrm{F}(22,2455)=344.68 \\
\text { Prob }>\mathrm{F}=0.0000\end{array}$} \\
\hline Residual & 75.9177676 & 2455 & \multicolumn{2}{|c|}{0.030923734} & \multicolumn{2}{|c|}{$\begin{array}{c}\text { R-squared }=0.7554 \\
\text { Adj R-squared }=0.7532\end{array}$} \\
\hline Total & 310.411534 & 2477 & \multicolumn{2}{|c|}{0.125317535} & \multicolumn{2}{|c|}{ Root MS = 0.17585} \\
\hline ln_przedsiebiorca & Coef. & Sd & Err. & $\mathbf{t}$ & $P>|t|$ & $\begin{array}{l}\text { [95\% Conf. } \\
\text { Interval] }\end{array}$ \\
\hline ln_ludzki & 0.4794946 & 0.0086553 & 55.40 & 0.000 & 0.4625222 & 0.4964671 \\
\hline ln_spoleczny & 0.0756208 & 0.0110409 & 6.85 & 0.000 & 0.0539703 & 0.0972712 \\
\hline
\end{tabular}


Table 8. Cont.

\begin{tabular}{ccccccc}
\hline Source & SS & df & \multicolumn{2}{c}{ MS } & \multicolumn{2}{c}{ Number of obs $=2478$} \\
\hline aglomeracja & 0.1294518 & 0.0107977 & 11.99 & 0.000 & 0.1082782 & 0.1506255 \\
ln_turystyka & 0.0207121 & 0.0037002 & 5.60 & 0.000 & 0.0134563 & 0.0279679 \\
hel & 0.3055209 & 0.1771875 & 1.72 & 0.085 & -0.0419316 & 0.6529734 \\
krynica_morska & 0.9267026 & 0.1777555 & 5.21 & 0.000 & 0.5781364 & 1.275269 \\
karpacz & 1.63965 & 0.1769733 & 9.26 & 0.000 & 1.292618 & 1.986683 \\
dolnoslaskie & -0.0489085 & 0.02135 & -2.29 & 0.022 & -0.0907743 & -0.0070427 \\
kujawskopomorskie & -0.1929891 & 0.022178 & -8.70 & 0.000 & -0.2364785 & -0.1494996 \\
lodzkie & -0.2436181 & 0.0211859 & -11.50 & 0.000 & -0.2851622 & -0.2020739 \\
lubelskie & -0.4391659 & 0.0204643 & -21.46 & 0.000 & -0.479295 & -0.3990368 \\
lubuskie & -0.1547316 & 0.0258805 & -5.98 & 0.000 & -0.2054815 & -0.1039817 \\
malopolskie & -0.1908125 & 0.0211241 & -9.03 & 0.000 & -0.2322354 & -0.1493896 \\
mazowieckie & -0.2285004 & 0.0193644 & -11.80 & 0.000 & -0.2664726 & -0.1905282 \\
opolskie & -0.1957349 & 0.0266379 & -7.35 & 0.000 & -0.24797 & -0.1434998 \\
podkarpackie & -0.437788 & 0.0216074 & -20.26 & 0.000 & -0.4801585 & -0.3954174 \\
podlaskie & -0.408201 & 0.0231601 & -17.63 & 0.000 & -0.4536164 & -0.3627856 \\
pomorskie & -0.0885853 & 0.0229874 & -3.85 & 0.000 & -0.133662 & -0.0435086 \\
slaskie & -0.175176 & 0.0217404 & -8.06 & 0.000 & -0.2178074 & -0.1325445 \\
swietokrzyskie & -0.379606 & 0.0239911 & -15.82 & 0.000 & -0.4266509 & -0.3325611 \\
warminskomazurskie & -0.3060869 & 0.0232286 & -13.18 & 0.000 & -0.3516366 & -0.2605372 \\
wielkopolskie & -0.072992 & 0.0202305 & -3.61 & 0.000 & -0.1126627 & -0.0333213 \\
_cons & 5.824715 & 0.0434177 & 134.16 & 0.000 & 5.739576 & 5.909854 \\
\hline
\end{tabular}

Referring to the main explained variables, an increase in the level of social capital in the municipality by $1 \%$ results in an increase in the number of enterprises registered in a municipality by $0.07 \%$ (seven hundredths of a percent). The estimate value for the agglomeration variable is 0.14 . This means that if this variable changes from 0 to 1 , the number of enterprises registered in a municipality will increase by $14 \%$. In the variable voivodeship, the reference category against which comparisons are made is Zachodniopomorskie voivodeship characterised by the highest entrepreneurship coefficient. The level of entrepreneurship in the remaining voivodeships deviates from it in a negative direction, which is reflected in negative values of coefficient estimates for individual voivodeships. Lubelskie and Podkarpackie voivodeships are most deviated in a negative direction from the level observed in Zachodniopomorskie voivodeship-by $44 \%$. On the other hand, the Dolnoślaskie and Wielkopolskie voivodships are the least negatively deviated ones: by $5 \%$ and $7 \%$, respectively. A very interesting result is the one for the Mazowieckie voivodeship, which is as much as minus $23 \%$ compared to the Zachodniopomorskie voivodeship. The Mazowieckie voivodeship can be treated as two different regions: the Warsaw agglomeration and the rest of the voivodeship, which is moderately developed compared to the rest of the country. If human capital—the percentage of people with higher education in the municipality-increases by $1 \%$ (relative to the initial value), the number of enterprises in the municipality will increase by $0.48 \%$ (i.e., half a percent). The estimated dependence is therefore very strong, as it means that human capital has a large impact on the number of enterprises registered in the municipality. The analogous effect on tourism is, however, much weaker: an increase in the value of this variable by $1 \%$ is associated with an increase in the number of enterprises by $0.02 \%$ (two hundredths of a percent).

The analyses carried out confirmed a positive and statistically significant correlation between the number of enterprises in a municipality per ten thousand inhabitants and human capital (H1), social capital $(\mathrm{H} 2)$, tourist attractiveness (H3), agglomeration (H4). On the other hand, there are very few municipalities which reach the predicted value approximate to the observed value without using one of the main resources. A strong influence of resources on entrepreneurship enables the formulation of the fifth hypothesis (H5) that the creation of entrepreneurship by local authorities is a trace phenomenon and its level is mainly determined by the resources of a given municipality. On the basis of the model, it can be assumed that attempts to stimulate entrepreneurship without taking the characteristics of the municipality and its natural resources into account will have little effect. 
The success of the municipality will be determined primarily by the resource "pension" (the sum of accumulated resources over the years) and the ability to manage it. The optimal strategy for local authorities is to adapt tools stimulating entrepreneurship to their resources.

When analysing the influence of individual variables on entrepreneurship, a strong correlation between the dependent variable and higher education is visible. Human capital causes the highest growth in entrepreneurship in the model, per $1 \%$ of growth in entrepreneurship. There is concern that the impact of this variable on entrepreneurship may be partially apparent. The study sought to reduce the impact of this variable by including other independent variables potentially correlated with human capital and entrepreneurship. Further attempts to make sure that the impact of human capital on entrepreneurship is not apparent would require the inclusion of data from the individual level in the model and the transfer of analyses to the level of individual enterprises. This is the biggest challenge for this stage of analysis. On the other hand, the theory clearly indicates the positive impact of human capital on entrepreneurship in the conditions of the development of Industry 4.0 [41-44,69]. The very high strength of this relationship remains the main doubt. The communist past of Poland and the strong link between higher education and agglomerations may constitute an explanation. In the Polish People's Republic, there was no such a demand for white-collar workers as we have in the current economy, and the transformation and new production methods forced changes in the structure of education. New, better paid jobs have increased demand for education. Systemic changes released a huge amount of resources and caused their relocation, which affected Poland in the regional aspect and further strengthened the growth in agglomeration importance. The liquidation of old jobs, such as local industrial plants or State Agricultural Enterprises, resulted in the outflow of people from smaller towns to cities and their agglomerations. Taking into account both the enormous changes in the Polish economy and the development of Industry 4.0, one can formulate a thesis that the results related to human capital are so high as a result of mutual support of global and national trends. The intensification of the human-machine relation resulting from the development of Industry 4.0 [70], puts greater demands on employees, which increases the importance of human capital. The need to develop human capital in companies introducing technologies 4.0 is also confirmed by other studies [71]. This means that there is a need for appropriate changes in vocational training systems [72] and this should be the task of regional authorities.

A large role of human capital is consistent with global research, however, currently the key role in spatial analyses of the economy is played by knowledge and agglomeration $[35,64,65]$.

Our research shows that a $1 \%$ increase in the value of the tourism variable is related to an increase in the number of enterprises by $0.02 \%$ (two hundredths of a percent). This is a much weaker dependence compared to human capital; however, it is also noticeable. This variable, however, enables a significant increase in the number of observations explained by the model because many atypical observations (the three most important ones include Karpacz, Krynica Morska and Hel) are related to tourism, and 11 of them are among the 20 municipalities with the largest number of enterprises per ten thousand inhabitants. Tourist municipalities have very strong brands being created over the years. Attempts to take over potential customers by other municipalities will be very difficult and require large financial outlays or the building of large tourist attractions. However, this is possible and seems to be an appropriate strategy in the context of opportunities and threats accompanying the development of Industry 4.0. Such opportunities are available, among others, to attractively located former industrial areas, where the currently liquidated industries used to dominate [73]. It is also worth to take actions in order to restore the attractiveness of regions experiencing a tourism crisis, as the benefits of tourism are diverse and lasting [74].

The activities of municipalities on the Internet and the development of digital products to influence consumer purchasing decisions are also important [75]. According to the Pencarella study (2019), in the near future, tourism ecosystems and territories will not only be able to rely only on digital innovations, but will have to take intelligent tourism prospects into account, such as sustainability, closed economy, 
quality of life and social value; they should also strive to improve the quality of tourism and increase the competitive advantage of intelligent tourist destinations [59].

The key prerequisite for the creation of the tourist profile of the region is having adequate resources-natural or created tourist attractions. This means that a local development strategy based on tourism is not possible for every municipality.

The problem of seasonality in regions with tourist specialisation should also be noted. Empty tourist facilities take up space and seem to be dead, which discourages tourists in the low season. It resembles the problem of empty "second homes" during the off-season in the Austrian Alps [76]. Outside the summer season, most coastal towns are at most half-dwelt settlements. Seasonality of tourist traffic and decisions to invest in education of children lead to outflow of highly qualified people from tourist towns. At the same time, the interaction in the model shows that tourism entrepreneurship needs people with high human capital for the purposes of development. To sum up, it seems that in order to resolve the biggest problem of these municipalities it is necessary to maintain or acquire people with high human capital.

The agglomeration variable is theoretically very important. The model takes all municipalities located in voivodship agglomerations into account. The average number of enterprises registered in a municipality belonging to an agglomeration is by $14 \%$ higher than in a municipality not belonging to an agglomeration, with the values of the other variables remaining unchanged. This is a very good result. The municipalities which stand out against Poland are located in the Warsaw and Poznan agglomerations in particular (as atypical observations). In Poland, the differences between the Warsaw agglomeration and the rest of the voivodship are particularly worrying. This shows that the differences between the central and peripheral regions are broadening. The factors that hinder this process, such as the transfer of production from Warsaw, are conducted rather within the agglomeration. The development of Industry 4.0 is also likely to be beneficial for agglomerations or regions in close proximity to agglomerations. From the point of view of other regions, this would be an extremely unfavourable phenomenon due to the fact that an agglomeration is a completely independent resource, as opposed to tourist attractiveness. However, studies of the criteria for the selection of locations for Industry 4.0 show that companies will move from existing industrial centres, where access to labour or raw materials has been an asset, and choose environmentally friendly locations [77]. It seems that investors are unlikely to abandon the agglomeration because of the still significant transport costs and the change in the structure of demand for workers-they will need fewer but more skilled workers. As previously demonstrated, a higher level of human capital is observed in metropolitan regions. Moreover, as the research of the North Jutland region shows, a considerable challenge for regions located far away from a metropolis may be the distance from important markets and industrial partners [78]. Other authors claim that even though industry 4.0 was theoretically supposed to make it possible to produce everything in any place, the production places have remained unchanged for years [79] and that the role of industrial clusters will not diminish [80-83]. This seems to be caused by the fact that the benefits of the agglomeration are still very important for many companies. Analysing the well-developed industrial region of Stuttgart, Hertwig et al. (2019) claim that with little effort, the local administration is able to support a symbiosis of sustainable development goals, Industry 4.0 and the goals of enterprises in the area [83]. Given the opportunities that industrial development 4.0 opens up for agglomeration areas, it is also necessary to take the emerging requirements for these areas into account- the need for adequate infrastructure and basic resources, such as water and energy and warning systems [84]. A very interesting observation also refers to the possibility of switching entire clusters (Marshall's industrial districts) to 4.0 solutions [85]. Institutional isomorphism, conditioned by adequate social capital, can play a key role here [85].

For social capital, an increase in the value of this variable by $1 \%$ is associated with an increase in the number of enterprises by $0.07 \%$ (seven hundredths of a percent). This is more than three times higher than for the tourism variable. In some municipalities, the associations are used by the authorities to carry out tasks related to tourism and promotion. In other localities organisations 
connected with cultivating local traditions, implementing participatory budget or developing relations with municipalities from other countries are set up. Referring to the theory of social capital, higher trust between the inhabitants should be observed in municipalities with a large number of associations, and thus lower transaction costs [86-89]. There is also another factor related to entrepreneurship, i.e., high proactivity and flexibility of citizens [90], their ability and willingness to organise and implement their own projects and ideas. There is a kind of project experience that can be used for the development of one's own company, which is particularly important in the context of the likely need to change profession at least several times during one's career. A lower level of social capital, expressed, e.g., by communication problems, may have a significant impact on the adaptation to the requirements of Industry 4.0. These phenomena were noticed by Brixner et al. [91]. The studies referred to the scale of countries, but similar phenomena can be observed on a local scale.

\section{Discussion}

The progressive development of Industry 4.0 has and will have an increasing impact not only on the ways in which goods and services are produced, but also on society, the place of residence, the environment, modes of movement and many other areas of in which our world functions. Most of the studies to date focused on the opportunities offered to businesses and the requirements they have to meet to effectively implement 4.0 technologies. Relatively few researchers focus on the regional aspect of the technological revolution, and if they do, their research covers only selected issues such as tourism or the specificity of local labour markets. The authors of this article take a different, more general perspective on the analysis of the consequences of the changes taking place.

The aim of the article was to show possible consequences of the development of Industry 4.0 from the local perspective. The authors assumed that 4.0 technologies increase the mobility of companies, which may pose a great threat to many existing industrial locations. What can secure local development in the long term and to some extent make regions independent of the backshoring threat is the creation of conditions for endogenous development of entrepreneurship. The article presents possible directions of changes in the profiles of local units and conditions that have to be met to enable such a transformation. The subject of the study was entrepreneurship measured by the number of companies in single local self-government units in Poland. The studies conducted have led to the following conclusions.

First of all, the adopted research model based on resources makes it possible to see a link between the possession of certain resources by a given location and the development of entrepreneurship, which is a guarantee of sustainable development of the location. In particular, there is a strong correlation between the level of human capital and the number of enterprises registered. Tourist attractiveness, location in the vicinity of an agglomeration and social capital are also important. A special value for the development of our learning model is the simultaneous inclusion of several variables, as so far the studies have focused on the analysis of individual local resources [35,42-44,64,65].

Secondly, the studies were conducted on a very large scale—all 2477 Polish municipalities were covered, which enables proper inference and generalisation. This has made it possible to identify regularities and find dependencies, as well as to exceptions, which sets the direction for further research. It will include a qualitative analysis of atypical cases.

Thirdly, in an environment of Industry 4.0 development and arising opportunities and threats, the studies carried out are of practical importance for some local authorities. This is because they indicate them the actions desired to create resources conducive to the development of enterprises. Although this does not apply to natural resources, such as the location by the sea or in the mountains, which determine the tourist attractiveness, the studies conducted indicate that also in the area of tourism, some resources may be anthropogenic. Human capital, social capital and even agglomeration (by improving the transport network) can also be those resources that local authorities can partially shape through skilful and consistent local development policies. 
Fourthly, the study carried out is relatively easy to replicate, which is very important for the development of knowledge from the analysed area. As our studies have shown the relationship between resources that are completely independent (geographical location, proximity to agglomerations) and those that are partly dependent on local authorities (human and social capital), it would be particularly valuable to carry out similar studies in other countries that are culturally and geographically different. It would also be interesting to extend our model by other variables. In addition, the durability of resources on which the growth in entrepreneurship is based, requires further in-depth analysis. This is of crucial importance from the perspective of sustainability of local communities.

Future research areas may focus on adding specific regional and cultural factors to the model. For example, identifying municipalities where collective agricultural production existed. Better operationalisation of the presence in an agglomeration can also bring new research values.

Author Contributions: Conceptualization, P.K. and J.P.; methodology, P.K.; validation, P.K., J.P.; formal analysis, P.K.; investigation, P.K.; resources, J.P.; data curation, P.K.; writing-original draft preparation, P.K. and J.P.; writing-review and editing, P.K. and J.P.; visualization, P.K. and J.P.; supervision P.K. and J.P. project administration, P.K. and J.P.; funding acquisition, J.P. and P.K. All authors have read and agreed to the published version of the manuscript.

Funding: This research received no external funding.

Conflicts of Interest: The authors declare no conflict of interest.

\section{References}

1. Górka, K.; Thier, A.; Łuszczyk, M. Consequeces of the Fourth Industrial Revolution in Social and Economic Development in the 21st. Century. In The Future of Management; Buła, P., Nogalski, B., Eds.; Jagiellonian University Press: Kraków, Poland, 2020; pp. 60-71.

2. Durana, P.; Kral, P.; Stehel, V.; Lazaroiu, G.; Sroka, W. Quality Culture of Manufacturing Enterprises: A Possible Way to Adaptation to Industry 4.0. Soc. Sci. 2019, 8, 124. [CrossRef]

3. Chiarini, A.; Belvedere, V.; Grando, A. Industry 4.0 strategies and technological developments. An exploratory research from Italian manufacturing companies. Prod. Plan. Control. 2020, 31, 1385-1398. [CrossRef]

4. Weking, J.; Stöcker, M.; Kowalkiewicz, M.; Böhm, M.; Krcmar, H. Leveraging industry 4.0-A business model pattern framework. Int. J. Prod. Econ. 2020, 225, 107588. [CrossRef]

5. Technological forecasting and social change: An international journal. Technol. Forecast. Soc. Chang. 1988, 34. [CrossRef]

6. Bilan, Y.; Rubanov, P.; Vasylieva, T.; Lyeonov, S. The Influence of Industry 4.0 on Financial Services: Determinants of Alternative Finance Development. Pol. J. Manag. Stud. 2019, 19, 70-93. [CrossRef]

7. Nagy, J.; Oláh, J.; Erdei, E.; Máté, D.; Popp, J. The Role and Impact of Industry 4.0 and the Internet of Things on the Business Strategy of the Value Chain-The Case of Hungary. Sustainability 2018, 10, 3491. [CrossRef]

8. Horváth, D.; Szabo, R.Z. Driving forces and barriers of Industry 4.0: Do multinational and small and medium-sized companies have equal opportunities? Technol. Forecast. Soc. Chang. 2019, 146, 119-132. [CrossRef]

9. Tortorella, G.L.; Vergara, A.M.C.; Garza-Reyes, J.A.; Sawhney, R. Organizational learning paths based upon industry 4.0 adoption: An empirical study with Brazilian manufacturers. Int. J. Prod. Econ. 2020, 219, 284-294. [CrossRef]

10. Bagis, M.; Karaguzel, E.; Kryeziu, L.; Ardic, K. A Longitudinal Analysis on Intellectual Structure of Human Resources Management: Theoretical Foundations and Research Trends. J. Mehmet Akif Ersoy Univ. Econ. Adm. Sci. Fac. 2019, 6, 796-814.

11. Van Rensburg, N.; Telukdarie, A.; Dhamija, P. Society 4.0 applied in Africa: Advancing the social impact of technology. Technol. Soc. 2019, 56, 101125. [CrossRef]

12. Zhang, W.; Gu, F.; Guo, J. Can smart factories bring environmental benefits to their products?: A case study of household refrigerators. J. Ind. Ecol. 2019, 23, 1381-1395. [CrossRef]

13. Varela, M.L.R.; Araújo, A.; Ávila, P.; Castro, H.; Putnik, G.D. Evaluation of the Relation between Lean Manufacturing, Industry 4.0, and Sustainability. Sustainability 2019, 11, 1439. [CrossRef] 
14. Bonilla, S.H.; Silva, H.R.O.; da Silva, M.T.; Gonçalves, R.F.; Sacomano, J.B. Industry 4.0 and Sustainability Implications: A Scenario-Based Analysis of the Impacts and Challenges. Sustainability 2018, 10, 3740. [CrossRef]

15. Müller, J.M.; Kiel, D.; Voigt, K.-I. What Drives the Implementation of Industry 4.0? The Role of Opportunities and Challenges in the Context of Sustainability. Sustainability 2018, 10, 247. [CrossRef]

16. Scavarda, A.; Daú, G.L.; Scavarda, L.F.; Caiado, R.G.G. An Analysis of the Corporate Social Responsibility and the Industry 4.0 with Focus on the Youth Generation: A Sustainable Human Resource Management Framework. Sustainability 2019, 11, 5130. [CrossRef]

17. Adamik, A.; Nowicki, M. Pathologies and Paradoxes of Co-Creation: A Contribution to the Discussion about Corporate Social Responsibility in Building a Competitive Advantage in the Age of Industry 4.0. Sustainability 2019, 11, 4954. [CrossRef]

18. Coban, M.; Kaymakci, O.T.; Gelen, G. Reliability Analysis of Assembly Processes Performed by Human-Robot Interaction. In Proceedings of the 2019 3rd International Symposium on Multidisciplinary Studies and Innovative Technologies (ISMSIT), Ankara, Turkey, 11-13 October 2019; pp. 1-8.

19. Dachs, B.; Kinkel, S.; Jäger, A. Bringing it all back home? Backshoring of manufacturing activities and the adoption of Industry 4.0 technologies. J. World Bus. 2019, 54, 101017. [CrossRef]

20. Stentoft, J.; Rajkumar, C. The relevance of Industry 4.0 and its relationship with moving manufacturing out, back and staying at home. Int. J. Prod. Res. 2020, 58, 2953-2973. [CrossRef]

21. Barbieri, P.; Ciabuschi, F.; Fratocchi, L.; Vignoli, M. What do we know about manufacturing reshoring? J. Glob. Oper. Strat. Sourc. 2018, 11, 79-122. [CrossRef]

22. Bilan, Y.; Kuzmenko, O.; Boiko, A. Research on the Impact of Industry 4.0 on Entrepreneurship in Various Countries Worldwide. In Education Excellence and Innovation Management through Vision 2020; Soliman, W.K., Ed.; Int Business Informat Management Assoc.: Granada, Spain, 2019; pp. 2373-2384.

23. Wefersova, J. Vision Sustainable Economic Development and Application of Innovation Management. In Proceedings of the 32nd Conference of the International-Business-Information-Management-Association (IBIMA), Seville, Spain, 15-16 November 2018; pp. 1777-1786.

24. Nam, T. Technology usage, expected job sustainability, and perceived job insecurity. Technol. Forecast. Soc. Chang. 2019, 138, 155-165. [CrossRef]

25. Pini, M. Family management and Industry 4.0: Different effects in different geographical areas? An analysis of the less developed regions in Italy. J. Entrep. Manag. Innov. 2019, 15, 73-102. [CrossRef]

26. Weng, L.; He, B.-J.; Liu, L.; Li, C.; Zhang, X. Sustainability Assessment of Cultural Heritage Tourism: Case Study of Pingyao Ancient City in China. Sustainability 2019, 11, 1392. [CrossRef]

27. Malihah, E.; Setiyorini, H.D. Industry Revolution 4.0: The Challenge for Secondary Education on Tourism and Hospitality in Indonesia. In Proceedings of the 5th UPI International Conference on Technical and Vocational Education and Training (ICTVET 2018), Bandung, Indonesia, 11-12 September 2018; pp. 464-467.

28. Hedvicakova, M.; Kral, M. Level of Industry Automation 4.0 in the Czech Republic and Impact on Unemployment. European Financial Systems 2018. Eur. Financ. Syst. 2018, 160, 2018.

29. Flynn, J.; Dance, S.; Schaefer, D. Industry 4.0 and Its Potential Impact on Employment Demographics in the UK. Adv. Transdiscipl. Eng. 2017, 6, 239-244.

30. Yudono, A.; Satria, D.; Erlando, A. Toward Inclusive Development Through Smart Economy in Malang Regency. IOP Conf. Series: Earth Environ. Sci. 2019, 328, 012008. [CrossRef]

31. Beauregard, R. Constituting Economic Development: A Theoretical Perspective. In Theories of Local Economic Development; Bingham, R., Mier, R., Eds.; SAGE Publications: Newbury Park, CA, USA, 1993; p. 275.

32. Melkers, J.; Bugler, D.; Bozeman, B. Technology Transfer and Economic Development. In Theories of Local Economic Development; Bingham, R., Mier, R., Eds.; SAGE Publications: Newbury Park, CA, USA, 1993; p. 233.

33. Gobar, A. The Need for Community Self-Evaluation. In Economic Development in Local Government; Kemp, R., Ed.; McFarland and Co.: Jefferson, NH, USA, 1995; p. 19.

34. Capello, R.; Nijkamp, P. Handbook of Regional Growth and Development Theories; Edward Elgar Publishing Limited: Cheltenham, UK, 2009; pp. 1-25.

35. Friedmann, J. World City Formation; Informa UK Limited: London, UK, 2018; pp. 57-66.

36. Bottazzi, G.; Dosi, G.; Fagiolo, G.; Secchi, A. Modeling industrial evolution in geographical space. J. Econ. Geogr. 2007, 7, 651-672. [CrossRef] 
37. Hindle, K. How community context affects entrepreneurial process: A diagnostic framework. Entrep. Reg. Dev. 2010, 22, 599-647. [CrossRef]

38. Pasieczny, J. Development Determinants of Local Government Unit's Profiles. In Proceedings of the International Scientific Conference Hradec Economic Days, Hradec Králové, Czechia, 31 January-1 February 2017; pp. 673-681.

39. Tamásy, C. Determinants of regional entrepreneurship dynamics in contemporary Germany: A conceptual and empirical analysis. Reg. Stud. 2011, 40,365-384. [CrossRef]

40. Badinger, H.; Müller, W.G.; Tondl, G. Regional Convergence in the European Union, 1985- 1999: A Spatial Dynamic Panel Analysis. Reg. Stud. 2004, 38, 241-253. [CrossRef]

41. Sima, V.; Gheorghe, I.G.; Subić, J.; Nancu, D. Influences of the Industry 4.0 Revolution on the Human Capital Development and Consumer Behavior: A Systematic Review. Sustainability 2020, 12, 4035. [CrossRef]

42. Kim, P.H.; Aldrich, H.E.; Keister, L. A Access (Not) Denied: The Impact of Financial, Human, and Cultural Capital on Entrepreneurial Entry in the United States. Small Bus. Econ. 2006, 27, 5-22. [CrossRef]

43. Davidsson, P.; Honig, B.L. The role of social and human capital among nascent entrepreneurs. J. Bus. Ventur. 2003, 18, 301-331. [CrossRef]

44. Acs, Z.; Braunerhjelm, P.; Audretsch, D.; Carlsson, B. Knowledge spillover theory of entrepreneurship. Small Bus. Econ. 2009, 32, 15-30. [CrossRef]

45. Van Der Sluis, J.; Van Praag, M.; Vijverberg, W. Education and entrepreneurship selection and performance: A review of the empirical literature. J. Econ. Surv. 2008, 22, 795-841. [CrossRef]

46. Dakhli, M.; De Clercq, D. Human capital, social capital, and innovation: A multi-country study. Entrep. Reg. Dev. 2004, 16, 107-128. [CrossRef]

47. Leśniak-Łebkowska, G. Industry 4.0: Social Impacts and Operations Management Challenges. In The Future of Management; Buła, P., Nogalski, B., Eds.; Jagiellonian University Press: Kraków, Poland, 2020; p. 13.

48. Mankiw, N.G.; Romer, D.; Weil, D.N. A Contribution to the Empirics of Economic Growth. Q. J. Econ. 1992, 107, 407-437. [CrossRef]

49. Gedajlovic, E.; Honig, B.; Moore, C.B.; Payne, G.T.; Wright, M. Social Capital and Entrepreneurship: A Schema and Research Agenda. Entrep. Theory Pr. 2013, 37, 455-478. [CrossRef]

50. Putnam, R. Making Democracy Work, Civic Traditions in Modern Italy; Princeton University Press: Princeton, NJ, USA, 1993.

51. Bourdieu, P. The forms of capital. In Handbook of Theory and Research for the Sociology of Education; Richardson, J., Ed.; Greenwood Press: New York, NY, USA, 1986; pp. 241-258.

52. Welter, F.; Smallbone, D. Exploring the Role of Trust in Entrepreneurial Activity. Entrep. Theory Pr. 2006, 30, 465-475. [CrossRef]

53. Gwosdz, K.; Micek, G.; Kocaj, A.; Sobala-Gwosdz, A.; Świgost-Kapocsi, A. Industry 4.0 and the prospects for domestic automotive suppliers in Poland. In The Challenge of Digital Transformation in the Automotive Industry. Jobs, Upgrading and the Prospects for Development; Drahokupil, J., Ed.; ETUI: Brussels, Belgium, 2020; pp. 89-105.

54. Harlamova, M.; Kirikova, M. Towards the Trust Model for Industry 4.0. In Information and Communication Technologies; Springer Science and Business Media LLC: Berlin/Heidelberg, Germany, 2018; Volume 838, pp. 43-57.

55. Gambetta, D. Trust: Making and Breaking Cooperative Relations; Blackwell: Hoboken, NJ, USA, 1988; pp. $213-237$.

56. Pasieczny, J. Kreowanie marki gminy. Probl. Zarzadzania 2006, 3, 74-90.

57. Dimeska, H. Creative tourism as a new paradigm in the development of cultural tourism in the republic of macedonia. In Proceedings of the International Scientific Conference Geobalcanica, Skopje, Macedonia, 20-21 May 2017; pp. 153-160.

58. Stankov, U.; Gretzel, U. Tourism 4.0 technologies and tourist experiences: A human-centered design perspective. Inf. Technol. Tour. 2020, 22, 477-488. [CrossRef]

59. Pencarelli, T. The digital revolution in the travel and tourism industry. Inf. Technol. Tour. 2020, 22, 455-476. [CrossRef]

60. Christaller, W. Central Places in Southern Germany; Prentice Hall: Upper Saddle River, NJ, USA, 1966; pp. 15-200.

61. Perroux, F. Note sur la Notion de "Pole do Croissance". Econ. Appl. 1955, 7, 307-320.

62. Krugman, P. The New Economic Geography, Now Middle-aged. Reg. Stud. 2010, 45, 1-7. [CrossRef] 
63. Friedmann, J. The World City Hypothesis. Dev. Chang. 2008, 17, 69-83. [CrossRef]

64. Taylor, P. Regionality in the world city network. Int. Soc. Sci. J. 2004, 56, 361-372. [CrossRef]

65. Smętkowski, M.; Gorzelak, G. Metropolis and its Region-New Relations in the Information Economy1. Eur. Plan. Stud. 2008, 16, 727-743. [CrossRef]

66. Neffke, F.; Henning, M.; Boschma, R. How Do Regions Diversify over Time? Industry Relatedness and the Development of New Growth Paths in Regions. Econ. Geogr. 2011, 87, 237-265. [CrossRef]

67. Boschma, R.; Minondo, A.; Navarro, M. The Emergence of New Industries at the Regional Level in Spain: A Proximity Approach Based on Product Relatedness. Econ. Geogr. 2013, 89, 29-51. [CrossRef]

68. De Vaan, M.; Frenken, K.; Boschma, R. The Downside of Social Capital in New Industry Creation. Econ. Geogr. 2019, 95, 315-340. [CrossRef]

69. Almaadeed, M.A.A.; Ponnamma, D. Role of Research and Higher Education on Industry 4.0, Material Science as an example. In Proceedings of the 2020 IEEE International Conference on Informatics, IoT, and Enabling Technologies (ICIoT), Doha, Qatar, 2-5 February 2020; pp. 435-439.

70. Barata, J.; Cunha, P.R.; Coyle, S. Evolving manufacturing mobility in Industry 4.0: The case of process industries. J. Manuf. Technol. Manag. 2019, 31, 52-71. [CrossRef]

71. Hamada, T. Determinants of decision-makers' attitudes toward Industry 4.0 adaptation. Soc. Sci. 2019, 8, 140. [CrossRef]

72. Lund, H.B.; Karlsen, A. The importance of vocational education institutions in manufacturing regions: Adding content to a broad definition of regional innovation systems. Ind. Innov. 2019, 27, 660-679. [CrossRef]

73. Eugen, B.T. Studies regarding tourism development perspectives in the existing economical and environmental context. WSEAS Trans. Environ. Dev. 2019, 15, 197-203.

74. Canavan, B. Marketing a tourism industry in late stage decline: The case of the Isle of Man. Cogent Bus. Manag. 2015, 2. [CrossRef]

75. Electronic -Word Of Mouth in Tourism 4.0: Customer Review of Online Travel Agent. Int. J. Eng. Adv. Technol. 2019, 8, 705-708. [CrossRef]

76. Borsdorf, A. Second homes in Tyrol. Revue de Géographie Alpine 2013. [CrossRef]

77. Erdoğan, G. Land selection criteria for lights out factory districts during the industry 4.0 process. J. Urban Manag. 2019, 8, 377-385. [CrossRef]

78. Decker, A. Industry 4.0 and SMEs in the Northern Jutland Region. In Value Creation in International Business; Springer Science and Business Media LLC: Berlin/Heidelberg, Germany, 2016; pp. 309-335.

79. Fox, S. Fox Moveable Production Systems for Sustainable Development and Trade: Limitations, Opportunities and Barriers. Sustainability 2019, 11, 5154. [CrossRef]

80. Getts, M. Vistula University The Industry 4.0 Induced Agility and New Skills in Clusters. Foresight STI Gov. 2019, 13, 72-83. [CrossRef]

81. Götz, M.; Jankowska, B. Clusters and Industry 4.0-Do they fit together? Eur. Plan. Stud. 2017, 25, 1633-1653. [CrossRef]

82. Jasińska, K.; Jasiński, B. Clustres under Industry 4.0 Conditions-Case Study: The Concept of Industry 4.0 Cluster in Poland. Transform. Bus. Econ. 2019, 18, 802-823.

83. Hertwig, M.; Lentes, J.; Zimmermann, N.; Dangelmaier, M. Stuttart Region-Sustainable Industrialization in Stuttgart Metropolitan Region in Smart Metropolitan Regional. In Smart Metropolitan Regional Development; Vinod Kumar, W.T., Ed.; Springer: Singapore, 2019; pp. 175-238.

84. Balogun, A.-L.; Marks, D.; Sharma, R.; Shekhar, H.; Balmes, C.; Maheng, D.; Arshad, A.; Salehi, P. Assessing the Potentials of Digitalization as a Tool for Climate Change Adaptation and Sustainable Development in Urban Centres. Sustain. Cities Soc. 2020, 53, 101888. [CrossRef]

85. Hervas-Oliver, J.-L.; Estelles-Miguel, S.; Mallol-Gasch, G.; Boix-Palomero, J. A place-based policy for promoting Industry 4.0: The case of the Castellon ceramic tile district. Eur. Plan. Stud. 2019, 27, 1838-1856. [CrossRef]

86. Fussell, H.; Harrison-Rexrode, J.; Kennan, W.R.; Hazleton, V. The relationship between social capital, transaction costs, and organizational outcomes: A case study. Corp. Commun. Int. J. 2006, 11, 148-161. [CrossRef]

87. Jacques, D.C.; Marinho, E.; D'Andrimont, R.; Waldner, F.; Radoux, J.; Gaspart, F.; Defourny, P. Social capital and transaction costs in millet markets. Heliyon 2018, 4, e00505. [CrossRef] [PubMed] 
88. Chang, H.H.; Hung, C.-J.; Huang, C.Y.; Wong, K.H.; Tsai, Y.J. Social capital and transaction cost on co-creating IT value towards inter-organizational EMR exchange. Int. J. Med Inform. 2017, 97, 247-260. [CrossRef]

89. Svendsen, G.L.H.; Svendsen, G.T. On the wealth of nations: Bourdieuconomics and social capital. Theory Soc. 2003, 32, 607-631. [CrossRef]

90. Sadikin, A.; Salim, U.; Soerachman, M. Ethno-methodology study: Entrepreneurial resilience of Urang Banjar in South Kalimantan as the efforts to improve local economic sustainability in digitalization industry 4.0 era. Int. J. Sci. Technol. Res. 2020, 9, 1827-1831.

91. Brixner, C.; Isaak, P.; Mochi, S.; Ozono, M.; Suárez, D.; Yoguel, G. Back to the future. Is industry 4.0 a new tecno-organizational paradigm? Implications for Latin American countries. Econ. Innov. New Technol. 2020, 29, 705-719. [CrossRef]

Publisher's Note: MDPI stays neutral with regard to jurisdictional claims in published maps and institutional affiliations.

(C) 2020 by the authors. Licensee MDPI, Basel, Switzerland. This article is an open access article distributed under the terms and conditions of the Creative Commons Attribution (CC BY) license (http://creativecommons.org/licenses/by/4.0/). 